\title{
CENTRUM I PERYFERIA. OBRAZ MOSKWY W POWIEŚCI DMITRIJA GLUCHOWSKIEGO TEKST
}

\section{ЦЕНТР И ПЕРИФЕРИЯ. ОБРАЗ МОСКВЫ В РОМАНЕ ДМИТРИЯ ГЛУХОВСКОГО ТЕКСТ \\ THE CENTER AND THE PERIPHERY. THE IMAGE OF MOSCOW IN DMITRY GLUKHOVSKY NOVEL TEXT}

\author{
Aleksandra Zywert \\ Uniwersytet im. Adama Mickiewicza w Poznaniu, Poznań - Polska \\ azywert@amu.edu.pl
}

Słowa kluczowe: Dmitrij Głuchowski, Tekst, centrum, peryferia, Moskwa

Ключевые слова: Дмитрий Глуховский, Текст, центр, периферия, Москва

Keywords: Dmitry Glukhovsky, Text, the center, the periphery, Moscow

Abstract: Text is a novel of manners with elements of a thriller, a noir, and a detective novel (but the above-mentioned complementary elements fulfill only a supportive role, because the criminal intrigue exposed at the very beginning is treated marginally amounts to a starting point for deeper considerations of the psychological and sociological nature). Due to the peculiar presentation of the image of the Center (here: Moscow), Text fits into the vision of Moscow as the core of Russian predatory capitalism, exuberant consumerism, glitz, semblance and ruthless struggle for recognition in the ranking of successful people, which is presented in contemporary Russian literature. Its fundamental value is the fact that the realization of the author's idea is mainly due to the confrontation of megalopolis with images of the periphery, which can be regarded as satellite cities of the capital. In his perception of Russia, Glukhovsky is close to Roman Senchin and, similarly to the latter, he believes that the traditionally understood center-periphery, city-village conflict is disappearing, because eventually it turns out that (despite the spatial and social diversity) none of these places (mainly because of conspicuous regressive tendencies) does not give a person a chance for free development and self-realization.

Dmitrij Głuchowski, autor, który przebojem zdobył rosyjski rynek wydawniczy i błyskawicznie zyskał popularność dzięki postapokaliptycznej trylogii Metro (Mempo 2033, 2005; Mempo 2034, 2009; Mempo 2035, 2015) tym razem zdecydował się odejść od fantastyki i wejść w obszary realizmu.

Tekst jest powieścią społeczno-obyczajową z elementami thrillera, powieści noir, oraz kryminału (lecz wspomniane elementy uzupełniające spełniają wyłącznie służebną, bo wyeksponowana już na samym początku kryminalna intryga jest traktowana marginalnie, $w$ kategoriach 
przyczynku do głębszych rozważań o charakterze psychologiczno-socjologicznym). Świadczy o tym już konstrukcja utworu oparta na wyeksponowanej na samym początku utworu sytuacji granicznej - niewiarygodnego spiętrzenia osobistych nieszczęść, dramatów i rozczarowań. Oto główny bohater, były skazaniec Ilja Goriunow, wraca po siedmiu latach odsiadki w kolonii karnej w Solikamsku do rodzinnej miejscowości - podmoskiewskiej Łobni. Ma nadzieję na nowe życie, którego początkiem ma być spotkanie z matką - najważniejszą dla niego osobą i jednocześnie jedyną, która go nie zapomniała. Tak się jednak nie staje, bo po przybyciu do domu okazuje się, że ta ostania dwa dni wcześniej zmarła. Dramat Ilji powiększa jeszcze świadomość, że świat poszedł do przodu i jego dawni koledzy, a nawet dziewczyna, Wiera, już dawno żyją swoim życiem i nie są skorzy do odnowienia znajomości. W dodatku osoba, przez którą został niesłusznie skazany - Piotr Chazin, major moskiewskiej milicji - żyje spokojnie i dostatnio w stolicy Rosji. Dojmująca, błyskawicznie zwielokrotniona emocjonalnym szokiem po stracie matki samotność i poczucie wyobcowania powoduje, że Goriunow myśli tylko o zemście na swoim największym wrogu. Udaje się to zrealizować bardzo szybko - Ilja zabija Chazina pod jednym z modnych moskiewskich klubów. Zaskakująca nawet dla samego bohatera łatwość realizacji planu wzbudza w nim chęć poznania bliżej swojego dawnego prześladowcy. Przegląda telefon zmarłego i z zapisanych w nim wiadomości dowiaduje się o przygotowywanej nielegalnej akcji sprzedaży narkotyków. Sam, bez pieniędzy i perspektyw ich szybkiego zarobienia, Ilja postanawia "ożywić” zmarłego Chazina, przejąć jego tożsamość do czasu finalizacji transakcji.

Zaznaczony $\mathrm{w}$ tytule pracy problem konfliktu centrum-peryferia $\mathrm{w}$ tym przypadku jest wariantem znanego $\mathrm{i}$ wielokrotnie omawianego w literaturze przedmiotu konfliktu miasto-wieś. O ile jednak wcześniej (głównie w święcącej swoje największe sukcesy w latach 60-80. XX wie$\mathrm{ku}$, prozie wiejskiej) sprowadzał się on do apoteozy tzw. małej ojczyzny i opierał się de facto na prostym przełożeniu: miasto jest siedliskiem wszelkiego zła, zaś wieś - to ostoja pamięci historycznej i upostaciowanie prawdziwego, bo naturalnego, życia, współcześnie kwestie wzajemnych relacji i wpływów tych dwóch przestrzeni nie są już tak jednoznaczne. W utworach kolejnych współczesnych rosyjskich pisarzy (jak np. Roman Sienczyn, Siergiej Minajew czy Olga Sławnikowa) coraz częściej pojawiają się pytania o rzeczywistą kondycję peryferii jako przeciwwagi dla Centrum. Biorąc powyższe pod uwagę, można zaryzykować tezę, że Głuchowski ze swoim utworem nie tylko płynnie wpisuje się $\mathrm{w}$ tę tendencję, ale też proponuje interesujący wariant sposobu prezentacji problemu - obraz Moskwy zyskuje siłę wyrazu przede wszyst- 
kim poprzez konsekwentną cykliczną konfrontację z peryferiami. Dzieje się tak między innymi dzięki umiejętnie skonstruowanej koncepcji czasu powieściowego oraz idealnie zrównoważonym proporcjom ekspozycji obu tych terytoriów. W odróżnieniu od większości utworów poruszających ten problem, w Tekście dbałość o szczegóły, skrupulatność opisu poszczególnych miejsc jest taka sama zarówno w przypadku Moskwy, jak i peryferyjnej Łobni.

Czas powieściowy jest dwu, a nawet trójpoziomowy. Daje to autorowi możliwość balansowania pomiędzy różnymi jego wymiarami. $Z$ jednej strony czas jest skrupulatnie mierzony latami, miesiącami, dniami, godzinami (akcja utworu trwa tydzień, wiadomo też, że bohater przebywał w obozie pracy siedem lat) - ten czas jest wspólny dla wszystkich. $\mathrm{Z}$ drugiej $\mathrm{w}$ momencie przekroczenia progu rodzinnego domu, rusza czas indywidualny, mierzony kolejnymi porcjami ugotowanego przez matkę na przyjazd syna, kapuśniaku oraz postępami pracy nad niedokończonym rysunkiem. Powracający cyklicznie motyw jedzenia zupy - ostatniej rzeczy przygotowanej rękami zmarłej już teraz kobiety - to jednocześnie nić wiążąca Ilję z matką-symbolem domu, bezpieczeństwa i nadziei na nowe, spokojne, normalne życie. Nadzieja ta jednak bardzo szybko umiera i ostatecznie kolejne zjadane przez bohatera porcje kapuśniaku odmierzają tylko czas do końca jego życia. Najbardziej znacząca jest pod tym względem finałowa scena powieści, w której Głuchowski pisze:

Открыл, разделся, помыл руки, поставил щи греться. Оставалось как раз на тарелку. [...] Включил телек, стал смотреть новости: канал „Лайф”. $[\ldots]$ „В Москве совершено убийство сотрудника правоохранительных органов. [...] Следствие отрабатывает несколько версий...". [...] Доел щи, мякишем собрал последний сок. Спасибо, мам. Помыл посуду. Лилось пенным на дурацкий пистолет. Убрал посуду в шкаф. [...] Пробежал пальцами по книжным корешкам. Сел за стол: там белым кверху лежал бумажный лист. Илья перевернул - его студенческий неоконченный рисунок, иллюстрация к „Превращению”: наполовину человек, наполовину насекомое. Поискал карандаш, сел дорисовывать. Придумалось, как. Выходило херово. [...] Но Илья не сдавался: доводил картинку до ума, сколько времени хватило. Когда выламывали дверь, вставать не стал (Gluhovskij, https://www.livelib. ru/book/186988/readpart-tekst-dmitrij-gluhovskij).

Analogiczną rolę, jak widać, spełnia odnaleziony w pokoju rysunek - kolejny konkretny element rzeczywistości łączący przeszłość z teraźniejszością, klamra spinająca indywidualny czas. Pojawia się w powieści dwukrotnie. Na początku, kiedy Ilja po raz pierwszy przekracza próg domu, rysunek wywołuje falę wspomnień o tragicznym dniu aresztowania (zaczął nad nim pracować właśnie w ów feralny dzień) i staje się 
impulsem do zemsty na Chazinie. Ponownie motyw ten powraca $\mathrm{w}$ finale powieści, kiedy bohater zdaje sobie sprawę z przegranej i żegna się ze światem - postanawia wówczas go dokończyć, zagrać ostatni akord swojego życia. Tym samym pierwszy epizod symbolicznie otwiera indywidualny czas, drugi go ostatecznie i nieodwołalnie domyka. Jest swego rodzaju klepsydrą, w której miarowo i nieubłaganie przesypuje się "piasek z zupy". Istotny jest tu także temat rysunku - ilustracja do Przemiany (Die Verwandlung 1912) Franza Kafki. Podobnie jak Kafkowski Gregor, także Ilja ani nie wie w jakim właściwie świecie żyje, ani też w co konkretnie się przeistacza. Pewne jest tylko jedno - przemiana ta jest nieuchronna i nieodwracalna. $W$ tej sytuacji zjedzenie ostatniej porcji zupy i dopracowanie rysunku jest symbolicznym końcem „pożerania” czasu. Przemiana się dokonała. Kończy się zupa, kończy się czas, kończy się życie.

Trzecią płaszczyznę czasową wyznaczają, zapisane w telefonie wiadomości. Dzielą się one na dwie grupy oddzielone momentem śmierci Chazina. Pierwsza z nich - to prywatna korespondencja policjanta, czas zamknięty, ale pozwalający skutecznie uzupełnić luki w życiorysach niektórych (bo nie tylko samego Chazina) bohaterów. Druga, zawierająca wiadomości pisane przez Ilję wcielającego się w policjanta - to czas "ukradzionego" Chazinowi życia.

Koncepcja czasu współgra z autorskim konceptem przestrzeni. Przestrzeń jest wyraźnie trójdzielna, szczelnie zamknięta (co charakterystyczne dla Głuchowskiego), ograniczona do Moskwy, oddalonej o pół godziny jazdy pociągiem peryferyjnej miejscowości Łobnia oraz wirtualnego świata w telefonie. Sposób potraktowania kwestii miejsca, lokalności oraz geografii pozwala zaliczyć powieść Głuchowskiego do grupy tzw. moskiewskich tekstów, tym ciekawszych, że odzwierciedlających opozycję Centrum-peryferia głównie w kontekście, charakterystycznego dla współczesnych wysokorozwiniętych społeczeństw, zjawiska „nowej biedy" upostaciowanej w opozycji: bogaty mieszkaniec metropolii, Chazin versus biedny prowincjusz, Goriunow. Jak stwierdza Amartya Sen, zjawisko "nowej biedy" sprowadza się do strachu przed ostracyzmem z powodów ekonomicznych. „W bogatym społeczeństwie już samo bycie biednym stanowi upośledzenie. W kraju bogatym trzeba mieć zwykle większy dochód, by kupić dostateczną ilość towarów, umożliwiających funkcjonowanie społeczne, takie jak np. publiczne pokazywanie się bez wstydu" (Kulińska, http://www.biuletyn.agh.edu.pl/archiwum_bip/_ 2001/_87/18_87.html). "Nowa bieda" niekoniecznie musi być związana $\mathrm{z}$ ubóstwem materialnym, ale z kolei zwykle towarzyszy temu patologia rodziny oraz szeroko pojęty aspołeczny tryb życia. Wynika to bezpośrednio, jak wskazuje Lucyna Kulińska, z gwałtownego wzrostu aspira- 
cji konsumpcyjnych (rozbudzanych głównie przez media) przy jednoczesnej niemożności ich natychmiastowego zaspokojenia. $\mathrm{W}$ rezultacie w pierwszej kolejności pojawia się złość i frustracja, która w skrajnych przypadkach prowadzi do uaktywnienia się przemocy - podstawowej przyczyny „kryminalizacji ubóstwa” (Kulińska 2003: 157).

Uwzględniając charakter rozwoju cywilizacyjnego w XX wieku polegający na znaczącym nacisku na status wielkich metropolii oraz wyraźne uprzywilejowanie życia miejskiego jako synonimu postępowości, obraz Moskwy nabiera szczególnego znaczenia. Będąc od dawna najważniejszym przestrzennym obrazem $\mathrm{w}$ literaturze rosyjskiej, począwszy od XVI wieku występowała ona kolejno jako miasto wybrane (utrwalone w kolejnym stuleciu jako zbudowane według Bożego zamysłu święte Centrum będące jednocześnie świątynią, cmentarzem i cerkwią (Selemeneva, https://cyberleninka.ru/article/n/obraz-moskvy-v-russkoy-literaturenachala-xxi-veka), namacalny symbol siły i potęgi Rosji, najpotężniejsze europejskie miasto, uosobienie absolutyzmu. W XX wieku obraz ten został uzupełniony i zaktualizowany o nowe, oddające specyfikę zmieniających się czasów, treści'1. Po II wojnie światowej miasto to (jedyne w Europie, które z powodzeniem odparło niemieckie ataki) zostało uhonorowane tytułem "Miasto Bohater", stało się dumą i chlubą władzy radzieckiej a także nowym Centrum Świata, „wyzwaniem cywilizacyjnym, symbolem kultury, postępu i masowej edukacji [...] witryną nowego reżymu" (Zarzycka-Bérard 2012: 203) i Mekką światowego komunizmu².

\footnotetext{
1 Sielemieniowa pisze:

В литературе XX в. в образе Москвы актуализируются миф творения и его частные варианты - миф о строительной жертве, миф о клятвопреступлении и ритуальном убийстве (Москва - город на крови), миф о Москве - третьем Риме (Москва - город-храм) и эсхатологический миф (гибель старой Москвы вследствие цареубийства и разрушения традиционного уклада в эпоху революционных преобразований.
}

M.V. Selemeneva, Obraz Moskvy v russkoj literature načala XXI veka. [М. В. Селеменева, Образ Москвы В русской литературе начала XXI века]. Web. 14.11.2018. https://cyberleninka. $\mathrm{ru} /$ article/n/obraz-moskvy-v-russkoy-literature-nachala-xxi-veka.

${ }^{2}$ Ewa Zarzycka-Bérard podkreśla, że zmiany w topografii stolicy Rosji rozpoczęły się jeszcze w latach 30. XX wieku:

w Moskwie w 1935 roku wyburzono tradycyjną handlową dzielnicę przy Placu Czerwonym, aby zrobić miejsce dla paradnej „kompozycji architektonicznej”, zachowano jednak Kreml i cerkiew Wasyla Błogosławionego, symbole wielowiekowej tradycji państwowej. W przygotowaniu na przesunięcie centrum miasta na południowy zachód, gdzie miał stanąć gigantyczny Pałac Rad, wysadzono w powietrze katedrę Chrystusa Zbawiciela.

E. Zarzycka-Bérard. „Powojenna odbudowa Moskwy, Warszawy i Berlina”. Przeł. M. Ochab. Zeszyty Literackie 117 (2012/1): 206-207. Na ten temat zob. także V. Papernyj. Kul'tura Dva. Moskva: NLO, 2006. [В. Паперный. Культура Два. Москва: НЛО, 2006]. 
Po upadku Imperium obraz stolicy Rosji (głównie za sprawą okresu "drapieżnego kapitalizmu" lat 90. XX wieku) dość szybko się zmienił. Jak podkreśla jeden z badaczy, błyskawicznie przekształciła się ona w:

эпицентр капитализации государства с присущими для этапа первоначального накопления капитала реалиями, новой и характерной для времени мифологией, с новой системой присущих периоду глобализации кодов культуры (Lûsyj 2013: 175).

Zniknęła jej magia, stworzona zaledwie kilkadziesiąt lat wcześniej za sprawa Bułhakowowskiego Mistrza i Małgorzaty (Macmep u Mapzapuma, 1928-1930 i 1932), za to pojawiła się krwiożerczość (często symbolicznie wyeksponowana poprzez "czarną" odmianę realizmu reprezentowaną w tekstach wielu, nie tylko typowo "moskiewskich" pisarzy wszystkich pokoleń) ${ }^{3}$. W tę tendencję wpisuje się także Głuchowski.

Budując obraz Moskwy w oczach Ilji, autor w dużym stopniu pomija jej wizerunek z okresu komunizmu (Moskwa jako serce organizmu zrodzonego „z wiary jednego człowieka, Lenina” (Byron 2012: 128)), a kreuje go w oparciu o potoczne wyobrażenie o antycznym Babilonie - kwintesencji wielkomiejskiego kosmopolityzmu, krainie „władzy, pieniądza i siły" ${ }^{4}$ zdolnych zrównać człowieka z Bogiem. Moskwa - to Centrum świata, Ziemia Obiecana, przepustka do sukcesu i komfortowego życia. Jest ona jednak pilnie strzeżona i dostać się do niej mogą tylko nieliczni. Wizja "oblężonej twierdzy" pojawia się już w inicjalnym fragmencie utworu, kiedy po odbyciu kary bohater przyjeżdża pociągiem na Dworzec Jarosławski - najdalej wysunięty na północ dworzec moskiewski. Nie ma wówczas jeszcze prawa wstępu do miasta. Może tylko się przesiąść na pociąg, by je opuścić.

Głuchowski wprowadza paradoks - z jednej strony Moskwa jest miastem pod wieloma względami zamkniętym i funkcjonującym na zasadzie odwróconego labiryntu: nie każdy może do niej wejść, ale wyjść - już tak. Moskwa nie wszystkich do siebie wpuści, za to bez żalu wypędzi każdego. Z drugiej - miasto to funkcjonuje w ścisłym połączeniu z peryferiami rozumianymi nie tylko jako terytoria bezpośrednio

${ }^{3}$ Szerzej zob. A. Zywert. „Moskiewska czernucha. Wstydliwa strona miasta?”, Kultury Wschodniostowiańskie - Oblicza i Dialog 6 (2016): 259-272.

${ }^{4}$ Barbara Kozielska pisze:

Blichtr starożytnej metropolii olśniewał, a wędrowcy stawali mizerni i onieśmieleni niespotykaną potęgą tego miejsca. Bogactwo oraz ogrom tego miejsca zanurzonego w kolorowej i wielojęzycznej rozpuście sprawiły, że stało się ono centrum ówczesnego świata. Miasto zamieszkałe przez ludzi butnych, bez pokory i zwątpienia, ufnych we własne możliwości, dzięki którym - po schodach budowanej przez siebie wieży - mogliby stawać obok Boga,

B. Kozielska. „Globalopolis - cywilizacja miast”. Globalopolis, kosmiczna wioska szanse i zagrożenia. Red. R. Borkowski, Warszawa: Instytut Wydawniczy PAX, 2003: 168. 
przylegające do jej granic administracyjnych, a także miasta satelickie. "Uprzestrzennienie" ma tu duże znaczenie, bo pozwala uwypuklić rolę Moskwy "w procesach globalizacyjnych i w kształtowaniu mapy kultury, a zwłaszcza jej parametrów związanych z dominacją, podporządkowaniem, mediacją i oporem" (Rybicka 2014: 25) Widać wyraźnie, że autor promuje wertykalny model prezentacji Centrum, który zakłada, że „W centrum tworzone są kanony artystyczne, hierarchie wartości, normy stylistyczne, na peryferiach zaś owe kanony, normy oraz hierarchie wartości są w najlepszym wypadku recypowane" (Piotrowski 2010: 25). Niebagatelne znaczenie ma tu zastosowana przez autora perspektywa oglądu rzeczywistości z perspektywy allogenicznej - prowincjusza, który zna Moskwę, ale w niej nie mieszka, za to przez całe życie o tym marzy. Dlatego kiedy po siedmiu latach życia „в зазеркальном отражении Москвы" Ilja ponownie się w niej pojawia, sukcesywnie weryfikuje swoje młodzieńcze wyobrażenia o stolicy, burząc tym samym wszelkie funkcjonujące $\mathrm{w}$ potocznej świadomości społecznej warianty moskiewskiego mitu. Obserwujemy proces gradacji - każda następna wizyta bohatera $\mathrm{w}$ stolicy przynosi coraz większe rozczarowanie, wzmaga poczucie samotności, "bycia nie na swoim miejscu”, i staje się kolejnym przyczynkiem do coraz bardziej pesymistycznych refleksji życiowych.

Wysuwająca się na pierwszy plan hermetyczność miasta, jednoznacznie utrwalająca status centrum jako hegemona $\mathrm{w}$ odniesieniu do peryferii, nie ogranicza się tylko do kontroli na dworcach (zwłaszcza Jarosławskim, uważanym za jedną z najważniejszych, bo obsługującą połączenia ze wschodem Rosji i większością miast Azji, stacji kolejowych stolicy). Dla mieszkańców mniejszych rosyjskich miast pierwszą i często ostatnią rzeczą skutecznie blokującą im dostęp do miasta, są ceny. Boleśnie przekonuje się o tym także i Ilja, kiedy okazuje się, że nawet zwykły pierożek w obskurnej przydworcowej budce jest poza jego zasięgiem („цены в ларьке были московскими, а транспортные ему выдавали соликамскими" (Gluhovskij, https://www.livelib.ru/book /186988/readpart-tekst-dmitrij-gluhovskij).

Niebagatelne znaczenie w konstruowaniu wizji stolicy Rosji odgrywa chwyt sensorycznej geografii literackiej oraz mapowania przestrzeni poprzez wykorzystanie toponimów skutecznie zawłaszczających przestrzeń. Przykładowo, w tekście pojawiają się nazwy konkretnych obiektów architektonicznych - jednych z podstawowych nośników informacji o mieście jako symbolu centrum, idealnie odzwierciedlających binarność rosyjskiej ewolucji w warstwie kulturowej. Kluczem do obrazu metropolii jest, jak się wydaje, koncepcja o „wahadłowej ewolucji historii Rosji, w której rewolucjonistyczna, kosmopolityczna i eksperymentalna Kultu- 
ra Jeden niezmiennie przekształca się $\mathrm{w}$ imperialną, zastygłą $\mathrm{w}$ samozadowoleniu, monumentalną i nacjonalistyczną Kulturę Dwa" (Lipowiecki 2001: 296-297). Z tego względu w Tekście sąsiadują ze sobą emblematyczne miejsca historyczne, powiązane z kulturą wysoką (jak np. pomnik Gogola), niechlubną radziecką przeszłością (np. „гостиница «Украина», сталинский подарочный торт с мясом и железобетоном" (Gluhovskij, https://www.livelib.ru/book/186988/readpart-tekst-dmitrij-gluhovskij) i postkomunistyczną współczesnością (np. wieżowce City, czy Triochgorna Manufaktura, w budynkach której aktualnie mieści się centrum konsumpcjonizmu i hedonistycznej rozrywki: bary, kluby i restauracje, w których króluje „угар, тщеславие и половые гормоны” (Gluhovskij, https:// www.livelib.ru/book/186988/readpart-tekst-dmitrij-gluhovskij). Niektóre uznane przez autora za szczególnie istotne, punkty miasta są prezentowane dwuwymiarowo - ich obraz zawiera w sobie porównanie przeznaczenia poprzedniego i aktualnego. Przykładowo, wspomniany już pomnik Gogola - to dziś miejsce całkowicie zdewaluowane - punkt spotkań narkomanów i ludzi z marginesu społecznego („Там всепогодные алкаши толклись, помесь рокеров с бомжами" (Gluhovskij, https:// www.livelib.ru/book/186988/readpart-tekst-dmitrij-gluhovskij). Analogicznie Triochgornaja Manufaktura - kiedyś wielkie przedsiębiorstwo, dziś centrum wybujałego konsumpcjonizmu, szalonego, skrajnie hedonistycznego, opętańczego i autodestrukcyjnego świętowania namacalnie zaświadczającego o przynależności jego bywalców do elity społecznej.

Wierzchołkiem moskiewskiego świata niezmiennie pozostaje Kreml, którego sylwetka dobitnie zaświadcza o imperialnej potędze zarówno samego miasta, jak i całego kraju („Кремль сиял ослепительно, подсвеченный снизу, и не было ни единого здания на набережной, которое не пыталось бы ему вторить. Облака подзаряжались земным электричеством и флюоресцировали. Москва - сама себе светило, ей звезды не нужны" (Gluhovskij, https://www.livelib.ru/book/186 988/readpart-tekst-dmitrij-gluhovskij).

Tego rodzaju chwyt - przywołanie położonych w historycznym Centrum miejsc powoduje, że na ukształtowany mnemotopos jest nakładany kolejny, na nowo konfigurujący tę samą przestrzeń w świadomości społecznej. Dochodzi do sytuacji połączenia ekspozycji przestrzeni tabu (historycznej, nienaruszalnej, której ingerencja jest postrzegana w kategoriach świętokradztwa) z przestrzenią modyfikowaną, zaświadczającą o nieustannej gotowości (w ramach przekształceń obszarów mocno zurbanizowanych) do rewitalizacji i zmiany przeznaczenia konkretnych obiektów przy jednoczesnym dążeniu do zachowania tożsamości miej- 
sca (co jest opłacalne zarówno ze względów społecznych, jak i ekonomicznych) 5 .

W porównaniu ze stolicą, Łobnia jest przerażająco biedna. Zardzewiałe garaże, brudne ceglane baraki, szare odrapane bloki ze śmierdzącymi klatkami schodowymi, stara, pamiętająca jeszcze lata 80. XX wieku szkoła („Желто-белая, блочная, трехэтажная, окна трехчастные, как дети у домиков рисуют [...] Ее, кажется, ни разу не ремонтировали за последние лет двадцать" (Gluhovskij, https://www.livelib.ru/book /186988/readpart-tekst-dmitrij-gluhovskij) - wszystko to idealnie odzwierciedla koncepcję planowego i świadomego przyzwolenia na biedę $\mathrm{w}$, charakteryzującej się "ciągłym niezaspokojeniem i pogonią za nowością" (Gancarz, https://rebus.us.edu.pl/bitstream/20.500.12128/7119 /3/Gancarz_Wykluczenie_spoleczne_w_krajach_Unii_Europejskiej.pdf) kulturze konsumpcji i w rezultacie przekształca się w ikoniczne uosobienie pojęcia „wykluczenie społeczne" we współczesnym rozumieniu 6 . W przypadku Łobni obraz ten jest tym wyrazistszy, że pogłębiony o zjawisko "kryminalizacji ubóstwa", będące w dużej części pokłosiem krachu komunizmu, a po części jedną z cech społeczeństwa postindustrialnego, w którym "ludzie „wykluczeni i odrzuceni” uciekają się do [...] odrzucenia tych, którzy ich wykluczyli" (Kulińska 2003: 166).

Z płaszczyznami przestrzennymi konweniuje różny dla obu miejsc rytm upływu czasu. Czas moskiewski niewiarygodnie pędzi („Москвичи очень спешат жить" (Gluhovskij, https://www.livelib.ru/book /186988/readpart-tekst-dmitrij-gluhovskij), tworząc wrażenie, że jest to „miasto, które nigdy nie zasypia”. $Z$ kolei Łobnia - to miejsce, w którym czas stoi w miejscu - jest szara, brudna, ciemna, obskurna, biedna

${ }^{5}$ Szerzej na ten temat zob. Ł. Urbańczyk, "Zabytki poprzemystowe szansa rozwoju miast". Adaptacja obiektów zabytkowych do wspótczesnych funkcji użytkowych. Red. B. Szmygina et al. Warszawa-Lublin: Lubelskie Towarzystwo Naukowe, Międzynarodowa Rada Ochrony Zabytków ICOMOS, Politechnika Lubelska, 2009: 189-201. Web. 12.10.2018 http://bc.pollub.pl/Content/631/adaptacja.pdf.

${ }^{6}$ Jak wskazuje Aleksandra Gancarz,

Zgodnie z zestawieniem wspólnych cech definicji, przedstawionym $\mathrm{w}$ raporcie z ewaluacji programu Unii Europejskiej Poverty 3, wykluczenie społeczne:

- jest procesem dynamicznym i wielowymiarowym; często jest zjawiskiem kumulatywnym, prowadzącym do wielowymiarowej deprywacji;

- przejawia się brakiem lub niewystarczającym poziomem uczestnictwa w głównym nurcie społeczeństwa i dostępu do najważniejszych systemów społecznych, takich jak rynek pracy, edukacja, opieka medyczna, zabezpieczenie społeczne;

- może przejawiać się lub skutkować zerwaniem więzi rodzinnych i społecznych, utratą poczucia sensu i tożsamości;

- niesie z sobą zagrożenie związane z powielaniem modelu i „dziedziczeniem” pewnych cech warunkujących pokoleniowy charakter wykluczenia. Ibidem 
i przerażająco smutna w swojej bezperspektywiczności. Beznadzieja wyziera ze wszystkich opisów miejsc: domów (,Двор сложен из хрущевок: бурый кирпич, белые рамы. Перекошенная карусель припорошена. Голые березы шестиэтажные" (Gluhovskij, https://www.livelib.ru/ book/186988/readpart-tekst-dmitrij-gluhovskij), skwerów („Он оставил по левую руку лобненский скверик: четыре скамейки квадратом у подножия гигантской опоры ЛЭП, и кучкующиеся неподалеку березки, чахлые и калечные от соседства с высоким напряжением" (Gluhovskij, https://www.livelib.ru/book/186988/readpart-tekst-dmitrijgluhovskij), pomników („Прошел памятник самой Батарее, которая Лобню обороняла во время войны: постамент с древней зениткой, установленный как будто в обложенный гранитом огромный окоп. По внутренним стенам окопа - таблички с фамилиями павших геpoes" (Gluhovskij, https://www.livelib.ru/book/186988/readpart-tekstdmitrij-gluhovskij). Ukonstytuowany w punktach architektonicznych marazm, apatia, odrętwienie i niemoc przekłada się na kondycję mieszkających w Łobni ludzi. Wszyscy oni bądź wegetują, bądź czekają przyczajeni, by w odpowiednim momencie podjąć kolejną straceńczą próbę przeprowadzki do stolicy.

Opozycyjność tych dwóch przestrzeni zostaje uwypuklona także poprzez zastosowanie zabiegów animizacji i antropomorfizacji. Widziana oczami Ilji Moskwa przypomina kobietę-kameleona. Z jednej strony pewna siebie, poważna, a nawet oficjalna, $\mathrm{z}$ drugiej - brudna, spocona, zdenerwowana, podejrzliwa („Отыщут его быстро. Видео с камер наблюдения поднимут. В Москве этих камер - сто тридцать тысяч" (Gluhovskij, https://www.livelib.ru/book/186988/readpart-tekst-dmitrijgluhovskij), skacowana, w zależności od pory dnia i nocy dumna albo nieszczęśliwa. Przyciąga swoim rozmachem, karnawałowym bogactwem gigantycznych centrów handlowych, obietnicą nieustannego świętowania, a jednocześnie odpycha i przeraża swoją bezwzględnością, okrucieństwem i smrodem śmierci („в конце прелого московского июля, в духоту, когда тело вечно липкое, а трупы на вторые сутки уже воняют" (Gluhovskij, https://www.livelib.ru/book/186988/readpart-tekstdmitrij-gluhovskij). W tym ujęciu jej falowanie, nieprzewidywalność, zdolność do płynnego zacierania granic pomiędzy realnością a fantazją, nachalne i chełpliwe targowanie iluzją szczęśliwej przyszłości, podkreślone przez rozległość i różnorodność terytorialną, budzi nie tyle uwielbienie, co przerażenie.

Łobnia z kolei jest jeśli jeszcze nie całkiem martwa, to na pewno dogorywająca, ale jednocześnie oswojona, cierpliwa i bezpieczna, nawet jeśli tylko po to, by przyjąć śmierć swojego "zbuntowanego dziecka". Symptomatyczny w tym kontekście jest finałowy monolog głównego 
bohatera. Po ostatnim powrocie z Moskwy, Ilja zdaje sobie sprawę ze swojej ostatecznej porażki i stojąc $\mathrm{w}$ obliczu nieuniknionego - śmierci (nieistotne, fizycznej, czy tylko psychicznej), prosi zmarłą matkę o wybaczenie za popełnione błędy. Najistotniejszy w tym monologu jest jego inicjalny fragment.

Стучали колеса электрички, мелькали фонарные столбы, Москва за окном расплавилась и потекла, чтобы отлиться через полчаса Лобней. Москва не держала Илью, не отговаривала. Хочешь дохнуть - ну дохни. Москва Илье была мачехой, Москве на Илью было насрать. А Лобня - как мать: ждала (Gluhovskij, https://www.livelib.ru/book/186988/readpart-tekst-dmitrij-gluhovskij).

Choć całość monologu jest skierowana do matki jako konkretnej osoby, to wstęp rozszerza to pojęcie o terytorium rodzinnego miasta - klasycznej „ma-łej ojczyzny” symbolizującej swego rodzaju wymuszony lokalizm regresywny - Łobnia jest jedynym miejscem, w którym bohater nie boi się umrzeć.

Wizerunek Moskwy znacząco uzupełnia także kontrastowy i jednoznacznie wybiórczy sposób kreacji bohaterów. Mieszkańcy stolicy (nieważne, czy rodowici, czy napływowi) są zimni, wyrachowani, przebiegli, sprzedajni, fałszywi, bezwzględni i zdolni do największej podłości, byle tylko wejść (nawet, jeśli tylko pozornie) do grona wybrańców - ludzi sukcesu i z nieskrywaną wyższością spoglądać na rzesze bezskutecznie dobijających się do bram miasta prowincjuszy. Taka jest choćby dawna dziewczyna Ilji, która obiektywnie niczego szczególnego w życiu nie osiągnęła, ale z punktu widzenia prowincjusza - wspięła się na szczyt: wyszła za mąż za moskwianina i tym samym pozbyła się piętna nieudacznika. Zdecydowanie negatywnymi postaciami są też przedstawiciele prawa. Moskiewscy policjanci - to głównie zwykłe sprzedajne zbiry, które wchodzą w szemrane interesy z mafią, handlują narkotykami, usuwają niewygodnych świadków i są gotowi bez zażenowania dopuścić się największej podłości, byle tylko utrzymać wygodne dla nich status quo. W rezultacie Moskwa traci swój status świętego miasta i staje się symbolem Imperium, ale w nieco innym, niż dotąd znaczeniu. To cały czas Imperium, ale Imperium zła, okrucieństwa i jawnego (bo nierzadko $\mathrm{w}$ majestacie prawa) bezprawia.

Wniosek ten konweniuje z ustaleniami innych współczesnych rosyjskich pisarzy jak choćby Siergiej Minajew (Москва, я не люблю тебя 2012), Roman Sienczyn (Московские тени 2009), czy Olga Sławnikowa (Lekka głowa (Легкая голова 2011)). Podobnie jak w Tekście, także i w ich utworach na pierwszym miejscu znajduje się topos kariery, która daje wymierne poczucie władzy nad ludźmi. Owo straceńcze w swej istocie dążenie można zauważyć choćby u Sienczyna. Autor wprowadza boha- 
terów z prowincji ale tylko teoretycznie wpuszcza ich do stolicy. Odmawia im prawa na spełnienie, przekształca w ludzi-cienie i pozwala tylko oglądać Moskwę z okien ubogiego, totalnie zunifikowanego i przeludnionego molochu-,,sypialni", Bratiejewo.

Sławnikowa z kolei, co prawda nie tylko wpuszcza swojego bohatera-prowincjusza do stolicy, a nawet pozwala mu odnieść sukces, ale i tak skazuje go na przerażającą samotność. Maksim T. Jermakow - główny bohater Lekkiej głowy - jest klasycznym produktem współczesnej Moskwy: skrajny egoista i indywidualista głęboko uzależniony od dóbr konsumpcyjnych. Analogiczne wnioski pojawiają się u Siergieja Szargunowa. Moskwa, na co zwraca uwagę pisarz w swojej autobiograficznej Книге без фотографий (2011), stawia wyłącznie na ludzi sukcesu, nie zaś na sprawiedliwych i uczciwych. O ile jednak Szargunow widział, jak słusznie podkreśla Maria Siemionowa, że „что сила Москвы в связи с провинцией, в сохранении диалога между столичным представителем творческой интеллигенции и «последним крестьянином» из русской глубинки" (Selemeneva, https://cyberleninka.ru/article/n/ obraz-moskvy-v-russkoy-literature-nachala-xxi-veka), to na tle pozostałych autorów (w tym i Głuchowskiego) jest wyjątkiem.

Reasumując, powieść Tekst niewątpliwie wpisuje się w prezentowaną we współczesnej literaturze rosyjskiej wizję Moskwy jako jądra drapieżnego kapitalizmu, wybujałego konsumpcjonizmu, blichtru, pozoranctwa i bezwzględnej walki o miejsce w rankingu ludzi sukcesu. W tym ujęciu jego zasadniczym walorem jest fakt, że realizacja autorskiego zamysłu przebiega głównie dzięki konfrontacji megalopolis z obrazami peryferii, za jakie można uważać miasta satelickie stolicy. Nie ma tu jednak dialogu, jak u Szargunowa, bo uosobiona w obrazie Łobni prowincja, nawet jeśli bliska sercu bohaterów, jest miejscem smutnym, przygnębiającym, zastygłym, niewygodnym balastem dla eksportowego wizerunku nie tylko stolicy, ale i całej Rosji.

W rezultacie wielopoziomowego skontrastowania wydźwięk obu obrazów (stolicy i peryferii) jest równie pesymistyczny. Podobnie (choć nie tak jednoznacznie dramatycznie) jak u Romana Sienczyna w powieści rodzina Jołtyszewów (Елmышеbы 2009), i u Głuchowskiego de facto zanika tradycyjnie rozumiany konflikt centrum-peryferia, miasto-wieś, bo ostatecznie okazuje się, że (mimo przestrzenno-społecznego zróżnicowania) żadne $\mathrm{z}$ tych miejsc (głównie $\mathrm{z}$ uwagi łatwo zauważalne tendencje regresywne) nie daje człowiekowi szansy na swobodny rozwój i samorealizację. 


\section{Bibliografia}

Byron Robert. „Moskwa”. Przeł. A. Pokojska, Zeszyty Literackie 1 (2012): 125-134.

Gancarz Aleksandra. „Wykluczenie społeczne w krajach Unii Europejskiej - porównanie opinii studentów kierunków nauczycielskich z Polski i Francji”. Pedagogika międzykulturowa wobec wykluczenia społecznego i edukacyjnego. Red. T. Lewowicki, A. Szczurek-Boruta, J. Suchodolska. Toruń: Wydawnictwo Adam Marszałek, 2011: 229-250. Web. 10.10.2017. <https://rebus.us.edu.pl/bitstream/20.500.12128/7119/3/Gancarz_ Wykluczenie_spoleczne_w_krajach_Unii_Europejskiej.pdf $>$.

Gluhovskij Dmitrij. Tekst. Moskva: АCТ, 2017. [Глуховский Дмитрий. Текст. Москва: ACT 2017]. Web. 10.12.2018. https://www.livelib.ru /book/186988/readpart-tekstdmitrij-gluhovskij>.

Kafka Franz. „Przemiana”. Wybór prozy. Przeł. J. Kydryński. Wrocław: Zakład Narodowy im. Ossolińskich, 2018: 24-83.

Kozielska Barbara. „Globalopolis - cywilizacja miast”. Globalopolis, kosmiczna wioska szanse i zagrożenia. Red. R. Borkowski, Warszawa Instytut Wydawniczy Pax, 2003: 168-189.

Kulińska Lucyna. „Bieda w czasach globalnej obfitości”. Globalopolis, kosmiczna wioska szanse i zagrożenia. Red. R. Borkowski, Warszawa: Instytut Wydawniczy Pax, 2003: 146-167.

Kulińska Lucyna. Bieda w dobie globalizacji. Zjawisko biedy w krajach Zachodu. Web. 10.10.2018. <http://www.biuletyn.agh.edu.pl/archiwum_bip/_2001/_87/18_87.html>.

Lipowiecki Mark. „Nowy moskiewski styl”. Przeł. K. Osińska. Literatura na Świecie 10-11 (2001): 294-315.

Lûsyj Aleksandr Pavlovič. Moskovskij tekst: tekstologičeskaâ koncepciâ russkoj kul'tury, Moskva: Veče, Russkij impul's, 2013. [Люсый Александр Павлович. Московский текст: текстологическая концепция русской культуры, Москва: Вече, Русский импульс, 2013].

Papernyj Vladimir. Kul'tura Dva, Moskva: NLO, 2006. [Паперный Владимир. Культура Два, Москва: НЛО, 2006].

Piotrowski Piotr. Agorafilia. Sztuka i demokracja w postkomunistycznej Europie. Poznań: Rebis, 2010.

Rybicka Elżbieta. Geopoetyka. Przestrzeń i miejsce we wspótczesnych teoriach i praktykach literackich. Kraków: Uniwersitas, 2014.

Selemeneva Marina Valer'evna. Obraz Moskvy v russkoj literature načala XXI veka. [Селеменева Марина Валерьевна. Образ Москвы В русской литературе начала XXI века]. Web. 14.11.2017. https://cyberleninka.ru/article/n/obraz-moskvy-v-russkoy-literaturenachala-xxi-veka.

Sen Amartya. Nierówności. Dalsze rozważania. Przeł. I. Topińska przy współpracy M. Kochanowicza. Kraków: Znak, 2000.

Urbańczyk Łukasz. „Zabytki poprzemysłowe szansą rozwoju miast”. Adaptacja obiektów zabytkowych do wspótczesnych funkcji użytkowych. Red. B. Szmygin, Warszawa-Lublin: 
Wydawnictwo Lubelskiego Towarzystwa Naukowego, Międzynarodowej Rady Ochrony Zabytków ICOMOS, Politechniki Lubelskiej, 2009: 189-201. Web. 12.10.2018. <http://bc.pollub.pl/Content/631/adaptacja.pdf>.

Zarzycka-Bérard Ewa. „Powojenna odbudowa Moskwy, Warszawy i Berlina”. Przeł. M. Ochab. Zeszyty Literackie 117 (2012/1): 203-213.

Zywert Aleksandra. „Moskiewska czernucha. Wstydliwa strona miasta?”. Kultury Wschodniostowiańskie - Oblicza i Dialog 6 (2016): 259-272. 